\title{
Bending Characteristics of Laminated Wood Composites Made of Poplar Wood and GFRP
}

\section{Savojna svojstva lameliranog drva izrađenoga od topolovine i GFRP-a}

\author{
Original scientific paper • Izvorni znanstveni rad \\ Received-prispjelo: 22. 2. 2019. \\ Accepted-prihvaćeno: 14. 1. 2021. \\ UDK: $630 * 812.71 ; 630 * 832.286 ; 674 * 031.32$ \\ https://doi.org/10.5552/drvind.2021.1913
}

\begin{abstract}
In this study, 4 layers of $5 \mathrm{~mm}$ thick slats obtained by sawing method from poplar wood were used. Plain woven GRFP with low density and grammage of $100 \mathrm{~g} / \mathrm{m}^{2}$ (Type 1) and plain woven GRFP with high density and grammage of $200 \mathrm{~g} / \mathrm{m}^{2}$ (Type 2) were placed and glued between each layer. Polyvinyl acetate (PVAc-D4), Polyurethane (PU) and dual-component Epoxy (L285-resin and H285-hardener) adhesives were used for gluing the layers. Strength values (bending and modulus of elasticity) between the obtained layers were investigated. As a result of the study, it was determined that epoxy glue has higher strength than polyurethane and polyvinyl acetate glues; Type 2 plain woven fabric has higher strength than Type 1 plain woven fabric; and parallel load to the glue line results in higher performance than perpendicular load to the glue line.
\end{abstract}

Keywords: poplar; wood laminate; bending strength; modulus of elasticity

SAŽETAK • U radu se prikazuje istraživanje lameliranog drva izrađenoga od piljenjem proizvedenih topolovih platica debljine $5 \mathrm{~mm}$ složenih u četiri sloja. Između svakog sloja zalijepljena je plošno tkana GRFP tkanina male gustoće i površinske mase $100 \mathrm{~g} / \mathrm{m}^{2}$ (tip 1) i plošno tkana GRFP tkanina velike gustoće i površinske mase $200 \mathrm{~g} / \mathrm{m}^{2}$ (tip 2). Za lijepljenje drva i tkanine upotrijebljena su ova ljepila: polivinilacetatno (PVAc-D4), poliuretansko (PU) i dvokomponentno epoksidno (L285-mola i H285-otvrdnjivač). Istražene su vrijednosti čvrstoće (savijanje i modul elastičnosti) te je utvrđeno da epoksidno ljepilo ima veću čvrstoću nego poliuretansko i polivinilacetatno ljepilo. Nadalje, tkanina tipa 2 ima veću čvrstoću od tkanine tipa 1, a djelovanjem sile paralelno sa sljubnicom dobivena su bolja svojstva nego pri djelovanju sile okomito na sljubnicu.

Ključne riječi: topolovina, drvni laminati, čvrstoća na savijanje, modul elastičnosti

\section{INTRODUCTION 1. UVOD}

The value of forest products is also increasing due to the continuous decrease in forest resources and the increase of costs in the world. Due to the increase in furniture consumption, it will be possible to meet the demand for forest products by processing the forests in accordance with the scientific principles and to use the cut trees most efficiently. Lamination technique is used for efficient use of wood materials, removal of defects and formation of diagonal fibers in curved formations. With the developing technology, it is used as glued

\footnotetext{
${ }^{1}$ Author is researcher at Karabuk University, Furniture Design and Decoration Department, Safranbolu Vocational School, Karabük, Turkey.

2 Author is researcher at Usak University, Banaz Vocational School, Forestry Department, Usak, Turkey.

${ }^{3}$ Author is researcher at Zonguldak Bulent Ecevit University, Caycuma Vocational School, Interior Design Programme, Zonguldak, Turkey.
} 
laminated timber material, which has an important place in today's design world as a contemporary material that allows to reach the smallest part of the wood by applying small pieces of wood with the help of glue, allowing wider openings and any desired shape.

Regarding solid wood materials, laminated wood materials, which are superior in terms of aesthetic, economic, and technological properties, have been suggested to be preferred in skeletal elements that require strength, particularly in LVL (Laminated Veneer Lumber) furniture production (Eckelman, 1993). Laminated wood materials are used in columns and beams as building elements, and in furniture which is exposed to high static and dynamic forces, in particular by sticking the plaque coating plates hot or cold under prestress under high pressure, flat or inclined (Dongel, 1999).

There are many reports available in the literature on the effects of laminated layer thickness on mechanical properties (Braun and Moody, 1977; Moody, 1981; Youngquist et al., 1984; Keskin, 2001; Altınok et al., 2009; Percin et al., 2009) and glue type (Senay, 1996; Eren, 1998; Dongel, 1999; Guray et al., 2003) and different press pressure (Franklin Glue Comp, 1989; Dilik, 1997; Ulupınar, 1998;).

Tests with glass fiber reinforced materials were first carried out by Wangaard (1964) and Biblis (1965). In these initial experiments, both researchers made experiments using epoxy resin-treated one-way glass fiber on different types of solid wood materials. The first experiment on laminated beams was carried out by Theakson (1965). Experiments were carried out using water-based adhesive and epoxy adhesive with glass fiber woven, glass fiber felt and one-way untreated glass fiber in various shapes. The highest performance was achieved with one-way glass fiber. In recent years, some researches have been carried out on mechanical reinforcement of glass fiber and wood based structural materials (Pidaparti and Johnson, 1996; Hallström and Grenestedt, 1997; Fiorelli and Dias, 2006; Akgul et al., 2009; Ozalp et al., 2009; Riberio et al., 2009; Basterra et al., 2012; Borri et al., 2013; Mistak, 2013; Bal 2014a and 2014b; Osmannezhad et al., 2014; Bal, 2015; Bal and Ozyurt, 2015; Guntekin, 2015).

The elements (beams) under the influence of the bending force are divided into two groups as "horizontal laminar elements" and "vertical laminar elements" according to the applied force direction (Baird and Ozelton, 1990). When the load is applied perpendicular to the glue line, it is called horizontal, and when the load is applied parallel to the glue line it is called vertical element. Examples of horizontal and vertical laminar elements are given in Figure 1.

The aim of this study was to bond and thicken layers between $5 \mathrm{~mm}$ thick Populus nigra slats using polyvinyl acetate (PVAc-D4), polyurethane (PU-D4) and dual-component epoxy resin (L285-resin and H285-hardener) to determine the bending strength and modulus of elasticity of laminated wood materials produced in 4 layers by placing low-density and high density glass fiber fabric (GFRP) in order to strengthen the layers.
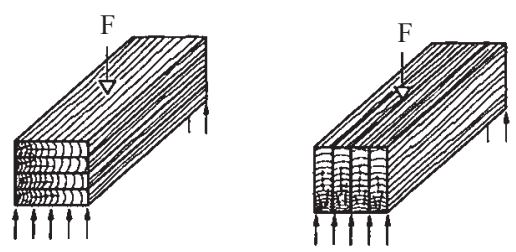

Figure 1 Examples of load perpendicular to glue line and parallel to glue line

Slika 1. Primjeri djelovanja sile okomito i paralelno na sljubnicu

\section{MATERIALS AND METHODS 2. MATERIJALI I METODE}

\subsection{Wood material}

2.1. Drvni materijal

The black poplar wood (Populus nigra) used as a solid wood in the preparation of the test specimens was obtained entirely randomly from lumber mills in Usak province. The choice of wood material was to ensure perfect timber, smooth fibers, without knots, with normal growth, no reaction wood, and no fungus and pest damage. The slats were cut from black poplar by a circular sawing machine with the dimension of $5 \mathrm{~mm} \times$ $70 \times \mathrm{mm} \times 1000 \mathrm{~mm}$. The slats were stored until reaching a moisture content of $12 \%$ in an air conditioning room with a temperature of $(20 \pm 2){ }^{\circ} \mathrm{C}$ and a relative humidity of $(65 \pm 5) \%$.

\subsection{Glass fiber fabric (GFRP)}

2.2. Tkanina ojačana staklenim vlaknima (GFRP)

It is produced from glass fiber materials such as fiberglass, silica, colemanite, aluminum oxide, soda. Glass fiber is the most known and used among fiber reinforced composites (Dost Kimya, 2017). Plain woven GFRP with low density and grammage of $100 \mathrm{~g} / \mathrm{m}^{2}$ (Type 1) and plain woven GFRP with high density and grammage of $200 \mathrm{~g} / \mathrm{m}^{2}$ (Type 2) were used between slats to improve the mechanical properties of timber structural elements and are shown in Figure 2.

\subsection{Glue}

2.3. Ljepilo

Polyvinyl acetate (PVAc-D4), Polyurethane (PU-D4) and Epoxy (L285 resin + H285-hardener) adhesives were used for bonding slats. Polyvinyl acetate adhesive (PVAc-D4) is an adhesive with advantageous properties such as odorless, easy application, quick curing, cold application and non-flammability (Polisan Ltd. Şti., 2017). Polyurethane adhesive (PUD4) is a one component, polyurethane based, fast and
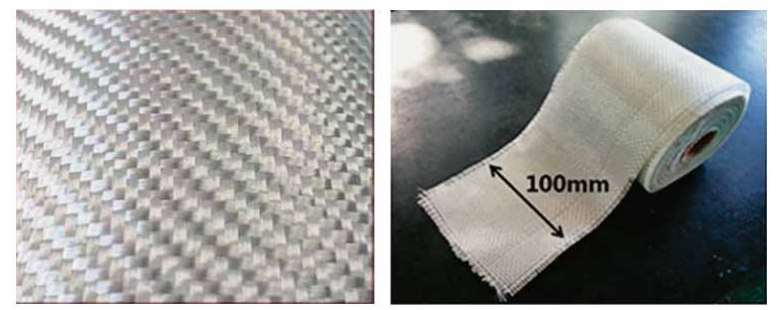

Figure 2 Glass Fiber Fabrics (GFRP)

Slika 2. Tkanina ojačana staklenim vlaknima (GFRP) 
moisture curing adhesive for indoor use (Polisan Ltd. Şti. 2017) and Epoxy (L285-resin+H285-hardener) is a polyurethane based (PU) dual component adhesive, which provides excellent adhesion to wood materials and achieves the desired mechanical strength (Dost Kimya, 2017).

\subsection{Preparation of experimental samples}

2.4. Priprema eksperimentalnih uzoraka

The test specimens were prepared according to the standard "TS EN 408:2010 + A1:2014-04 Timber and Glued Laminates - Determination of Some Physical and Mechanical Properties". During the production of the test specimens from air-dried $5 \mathrm{~mm}$ thick solid materials, 4 solid layers of PVAc-D4, PU-D and Epoxy glues and plain woven GFPR with low and high density interlayer materials and samples without interlayer (as a control) were produced. For interlayer samples, 3 layers of glass fiber material were used for intermediate support between solid layers. In the lamination process, the dimensions of slats are $5 \times 100 \times 1000 \mathrm{~mm}$ and 4 layers are bonded. In the case of samples of interlayer materials, the glue solution was applied to the solid bonding surfaces with a brush and glue spread of $180-200 \mathrm{gr} / \mathrm{m}^{2}$. In the bonding process, the surfaces are glued and kept for 5-6 minutes (open time). The cold laminating process was carried out by setting the pres- sure to $1.2 \mathrm{~N} / \mathrm{mm}^{2}$, cold in the hydraulic press with a pressure gauge suitable for hot and cold preseason for 8 hours (closed time). The laminated material obtained after pressing is prepared with woodworking machines according to the standard. The prepared samples are shown in Figure 3.

By using 2 plain woven types (control, Type 1 and Type 2), 3 glue types (PVAc-D4, PU-D4, and epoxy), 1 wood type (poplar) and 2 load types (bending strength and modulus of elasticity), a total of 90 samples $(3 \times 3 \times 1 \times 2 \times 5)$ were prepared with 5 replicates for each parameter. Prior to testing, all specimens were stored in a conditioning room maintained at $\left(20 \pm 2{ }^{\circ} \mathrm{C}\right)$ and $65 \% \mathrm{RH}$ until moisture equilibrium was achieved.

\subsection{Methods}

\subsubsection{Bending strength}

2.5.1. Čvrstoća na savijanje

The prepared test samples were tested, according to the 4-point bending principle, in parallel and perpendicular direction to the glue line using the SHIMADZU universal testing machine placed in the laboratory of Karabuk University Safranbolu Vocational School.

The loading speed of the test machine is $5 \mathrm{~mm} /$ min. The bending strength, modulus of elasticity and load carrying capacity of the specimens placed with the

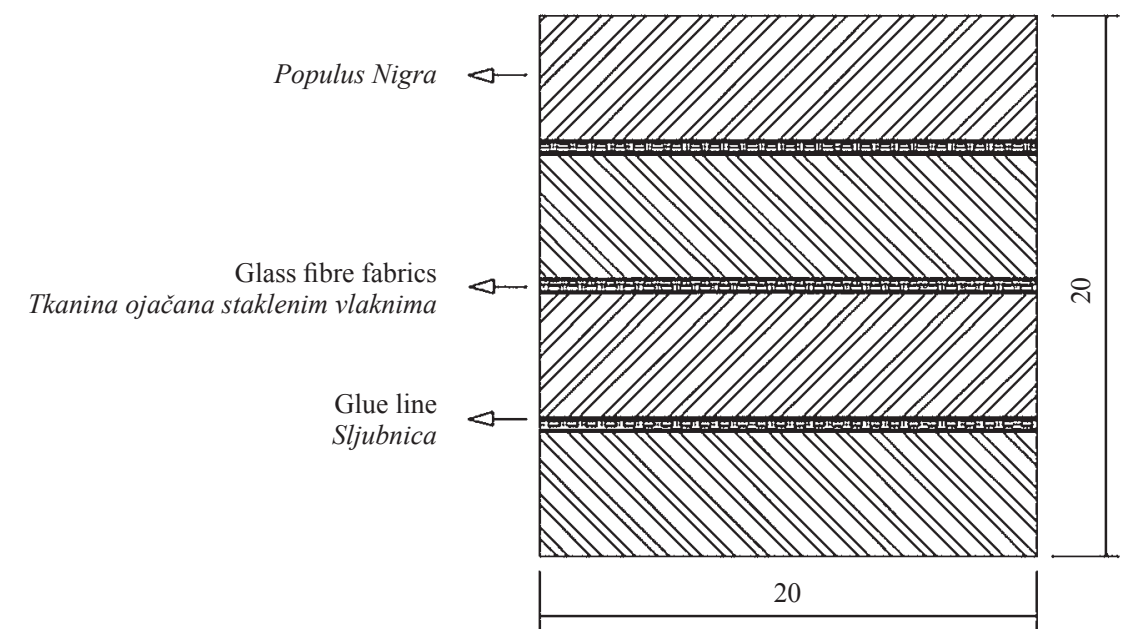

Figure 3 Test Samples of GFRP + Glue + Wood

Slika 3. Ispitni uzorci: GFRP + ljepilo + drvo

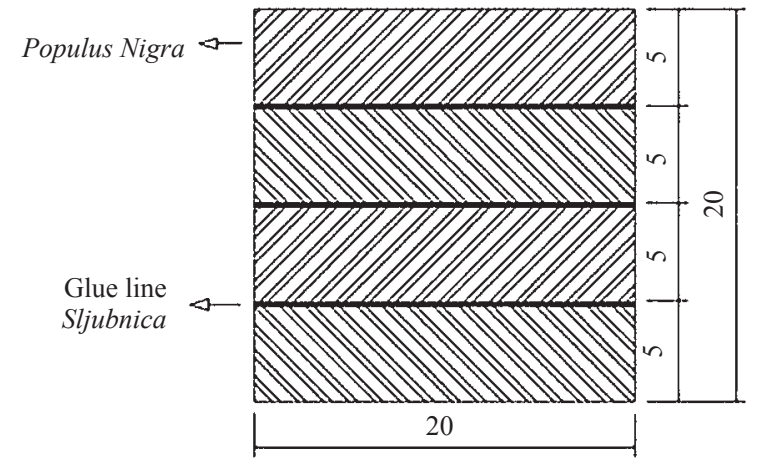

Figure 4 Test Samples of Glue + Wood

Slika 4. Ispitni uzorci: ljepilo + drvo 


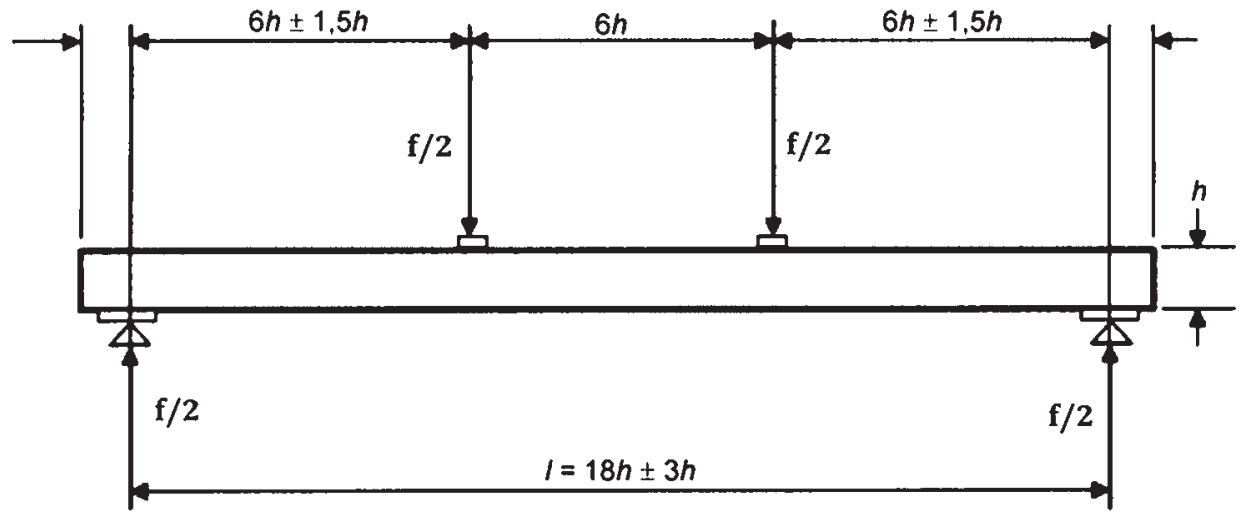

Figure 5 4-point bending principle

Slika 5. Načelo savijanja u četiri točke

base points of $360(\mathrm{~mm})$ are calculated. The 4-point bending strength was determined as (Eq. 1.):

$$
\sigma_{E 4}=\frac{F \cdot L}{b \cdot h^{2}}
$$

Where is bending strength $\left(\mathrm{N} / \mathrm{mm}^{2}\right), F$ is the maximum load $(\mathrm{N}), L$ is span $(\mathrm{mm}), b$ is width $(\mathrm{mm})$ and $h$ is thickness (mm).

\subsubsection{Modulus of elasticity}

\subsubsection{Modul elastičnosti} 2.):

The modulus of elasticity was determined as (Eq.

$$
E_{\mathrm{m} \cdot \mathrm{g} 4}=\frac{\lambda^{3} \cdot\left(F_{2}-F_{1}\right)}{b_{1} \cdot h_{1}^{3} \cdot\left(W_{2}-W_{1}\right)} \cdot\left[\left(\frac{3 a}{4 \lambda}\right)-\left(\frac{a}{\lambda}\right)^{3}\right]
$$

Where $E_{\mathrm{m} \cdot \mathrm{g} 4}$ is modulus of elasticity $\left(\mathrm{N} / \mathrm{mm}^{2}\right)$, $\lambda$ is length measured for identification of the modulus of elasticity, $b_{1}$ is width - dimension in tangential direction $(\mathrm{cm}), h_{1}$ is height - dimension in radial direction (cm), $a$ is distance between loading point and nearest spam (mm), $F_{2}-F_{1}$ is increase of the load ratio on the correct line of the load-deflection curve $(\mathrm{N})$, and $W_{2}-W_{1}$ is increase in deformation corresponding to $F_{2}-F_{1}(\mathrm{~mm})$.

\subsection{Evaluation of data}

\subsection{Evaluacija podataka}

Statistical results (arithmetic mean $X$, standard deviation $S S$ and coefficient of variation $\% \mathrm{~V}$ ) of the data obtained in the experiments were calculated. In order to determine the test results, multiple variance analysis (ANOVA) was used to determine the effect of factors on the values obtained for all groups. The Duncan test was used to indicate the significance level of the interaction of the factors $(p<0.05)$ with $5 \%$ error. Under the name of homogeneity group (HG), groups that differ were designated as $\mathrm{A}, \mathrm{B}, \mathrm{C}$, etc.

\section{RESULTS AND DISCUSSION 3. REZULTATI I RASPRAVA}

\subsection{Bending strength of parallel to glue line}

3.1. Čvrstoća na savijanje paralelno sa sljubnicom

According to the normality analysis test result, the regions show normal distribution. The statistical evaluation results of bending strength of laminated composite material and solid wood materials are given in Table 1 and results of multiple variance analysis are given in Table 2 .

The effect of glue type and glass fiber fabric type on the bending strength parallel to the glue line was significant $(p<0.05)$. The double interaction of the glue type and glass fiber fabric type $(p<0.05)$ was negligible with respect to the error. Duncan test results applied to determine which groups are different are given in Table 3 by glue type and Table 4 by glass fiber fabric type.

According to Table 4, the highest bending strength was obtained from Type 2, while the lowest bending strength sample was obtained from control samples.

Table 1 Bending strength values parallel to glue line $\left(\mathrm{N} / \mathrm{mm}^{2}\right)$

Tablica 1. Vrijednosti čvrstoće na savijanje paralelno sa sljubnicom $\left(\mathrm{N} / \mathrm{mm}^{2}\right)$

\begin{tabular}{|l|l|c|c|c|c|c|}
\hline $\begin{array}{l}\text { Glue type } \\
\text { Vrsta ljepila }\end{array}$ & GFRP & $\boldsymbol{X} \mathbf{m i n}$ & $\boldsymbol{X m a x}$ & $\boldsymbol{X}$ & $\boldsymbol{S S}$ & $\boldsymbol{\%} \boldsymbol{V}$ \\
\hline \multirow{3}{*}{ PVAc-D4 } & Control & 40.52 & 46.13 & 43.32 & 2.32 & 5.355 \\
\cline { 2 - 7 } & Type 1 & 47.02 & 52.64 & 49.83 & 2.67 & 5.358 \\
\cline { 2 - 7 } & Type 2 & 62.96 & 68.58 & 65.77 & 3.52 & 5.351 \\
\hline \multirow{3}{*}{ PU-D4 } & Control & 36.58 & 42.20 & 39.39 & 2.11 & 5.356 \\
\cline { 2 - 7 } & Type 1 & 42.49 & 48.11 & 45.30 & 2.43 & 5.364 \\
\cline { 2 - 7 } & Type 2 & 56.98 & 62.60 & 59.79 & 3.20 & 5.352 \\
\hline \multirow{3}{*}{ Epoxy } & Control & 52.64 & 58.26 & 55.45 & 2.97 & 5.356 \\
\cline { 2 - 7 } & Type 1 & 60.97 & 66.59 & 63.78 & 3.42 & 5.362 \\
\cline { 2 - 7 } & Type 2 & 81.38 & 87.00 & 84.19 & 4.50 & 5.345 \\
\hline
\end{tabular}

$S S$ - standard deviation / standardna devijacija; $V$ - coefficient of variation / koeficijent varijacije 
Table 2 Variance analysis results of the effects of glue type and glass fiber fabric type on bending strength values parallel to glue line

Tablica 2. Rezultati analize varijance utjecaja vrste ljepila i vrste tkanine ojačane staklenim vlaknima na čvrstoću na savijanje paralelno sa sljubnicom

\begin{tabular}{|l|c|c|c|c|c|}
\hline $\begin{array}{l}\text { Source of variance } \\
\text { Izvor varijance }\end{array}$ & $\begin{array}{c}\text { Sum of square } \\
\text { Zbroj kvadrata }\end{array}$ & $\boldsymbol{d f}$ & $\begin{array}{c}\text { Mean square } \\
\text { Prosječni kvadrat }\end{array}$ & $\begin{array}{c}\boldsymbol{F} \text { ratio } \\
\text { F-omjer }\end{array}$ & $\begin{array}{c}\text { Level of significance } \\
\text { Razina značajnosti }\end{array}$ \\
\hline Glue type (A) / vrsta ljepila (A) & 3146.130 & 2 & 1573.065 & 164.012 & .000 \\
\hline $\begin{array}{l}\text { Plain woven type (B) } \\
\text { vrsta plošno pletene tkanine (B) }\end{array}$ & 4522.027 & 2 & 2261.014 & 235.740 & .000 \\
\hline A x B & 99.787 & 4 & 24.947 & 2.601 & .062 \\
\hline Residual / ostatak & 345.281 & 36 & 9.591 & & \\
\hline Total / ukupno & 150810.086 & 45 & & & \\
\hline
\end{tabular}

Table 3 Duncan test results $\left(\mathrm{N} / \mathrm{mm}^{2}\right)$ of the effect of bending strength parallel to glue line by glue type Tablica 3. Duncanov test čvrstoće na savijanje $\left(\mathrm{N} / \mathrm{mm}^{2}\right)$ paralelno sa sljubnicom s obzirom na vrstu ljepila

\begin{tabular}{|l|c|c|}
\hline Glue type / Vrsta ljepila & $\boldsymbol{X}$ & HG \\
\hline Epoxy & 67.81 & A \\
\hline Polyvinyl Acetate (PVAc-D4) & 52.97 & B \\
\hline Polyurethane (PU-D4) & 48.16 & C \\
\hline
\end{tabular}

Table 4 Duncan test results of the effect of bending strength $\left(\mathrm{N} / \mathrm{mm}^{2}\right)$ parallel to glue line by glass fiber fabric type

Tablica 4. Duncanov test čvrstoće na savijanje $\left(\mathrm{N} / \mathrm{mm}^{2}\right)$ paralelno sa sljubnicom s obzirom na vrstu tkanine ojačane staklenim vlaknima

\begin{tabular}{|l|c|c|}
\hline GFRP & $\boldsymbol{X}$ & HG \\
\hline Type 2 / tip 2 & 69.92 & A \\
\hline Type 1 / tip 1 & 52.97 & B \\
\hline Control / kontrola & 46.05 & C \\
\hline
\end{tabular}

\subsection{B Bending strength perpendicular to glue line} 3.2. Čvrstoća na savijanje okomito na sljubnicu

The statistical evaluation results of bending strength of laminated wood material and solid wood are given in Table 5, and the results of multiple variance analysis are given in Table 6.

The effect of the type of glue and glass fiber fabric type on the vertical bending strength of the glue line was significant $(p<0.05)$. The double interaction of the glue type and glass fiber fabric type $(p<0.05)$ was negligible with respect to the error. Duncan test results applied to determine which groups are different are given in Table 7 by glue type and Table 8 by glass fiber fabric type.

According to Table 7, the highest bending strength was obtained from epoxy glue, while the lowest bending strength was obtained from polyurethane glue (PU-D4).

Table 5 Bending strength values perpendicular to glue line $\left(\mathrm{N} / \mathrm{mm}^{2}\right)$

Tablica 5. Vrijednosti čvrstoće na savijanje okomito na sljubnicu $\left(\mathrm{N} / \mathrm{mm}^{2}\right)$

\begin{tabular}{|l|c|c|c|c|c|c|}
\hline Glue type / Vrsta ljepila & GFRP & $\boldsymbol{X m i n}$ & $\boldsymbol{X m a x}$ & $\boldsymbol{X}$ & $\boldsymbol{S S}$ & $\mathbf{\%} \boldsymbol{V}$ \\
\hline \multirow{3}{*}{ PVAc-D4 } & Control & 38.49 & 43.83 & 41.16 & 2.20 & 5.344 \\
\cline { 2 - 7 } & Type 1 & 44.67 & 50.01 & 47.34 & 2.54 & 5.365 \\
\cline { 2 - 7 } & Type 2 & 59.81 & 65.15 & 62.48 & 3.34 & 5.345 \\
\hline \multirow{3}{*}{ PU-D4 } & Control & 34.75 & 40.09 & 37.42 & 2.00 & 5.344 \\
\cline { 2 - 7 } & Type 1 & 40.36 & 45.70 & 43.03 & 2.31 & 5.368 \\
\cline { 2 - 7 } & Type 2 & 54.13 & 59.47 & 56.80 & 3.04 & 5.352 \\
\hline \multirow{3}{*}{ Epoxy } & Control & 50.01 & 55.35 & 52.68 & 2.82 & 5.353 \\
\cline { 2 - 7 } & Type 1 & 57.92 & 63.26 & 60.59 & 3.25 & 5.363 \\
\cline { 2 - 7 } & Type 2 & 77.31 & 82.65 & 79.98 & 4.28 & 5.351 \\
\hline
\end{tabular}

$S S$ - standard deviation / standardna devijacija; $V$ - coefficient of variation / koeficijent varijacije

Table 6 Variance analysis results of the effects of glue type and glass fiber fabric type on bending strength values perpendicular to glue line

Tablica 6. Rezultati analize varijance utjecaja vrste ljepila i vrste tkanine ojačane staklenim vlaknima na čvrstoću na savijanje okomito na sljubnicu

\begin{tabular}{|l|c|c|c|c|c|}
\hline $\begin{array}{l}\text { Source of variance } \\
\text { Izvor varijance }\end{array}$ & $\begin{array}{c}\text { Sum of square } \\
\text { Zbroj kvadrata }\end{array}$ & $\boldsymbol{d f}$ & $\begin{array}{c}\text { Mean square } \\
\text { Prosječni kvadrat }\end{array}$ & $\begin{array}{c}\boldsymbol{F} \text { ratio } \\
\text { F-omjer }\end{array}$ & $\begin{array}{c}\text { Level of significance } \\
\text { Razina značajnosti }\end{array}$ \\
\hline Glue type (A) / vrsta ljepila (A) & 2839.409 & 2 & 1419.705 & 163.998 & 0.000 \\
\hline $\begin{array}{l}\text { Plain woven type (B) } \\
\text { vrsta plošno pletene tkanine (B) }\end{array}$ & 4080.998 & 2 & 2040.499 & 235.710 & 0.000 \\
\hline A x B & 89.964 & 4 & 22.491 & 2.598 & 0.057 \\
\hline Residual / ostatak & 311.646 & 36 & 8.657 & & \\
\hline Total / ukupno & 136106.147 & 45 & & & \\
\hline
\end{tabular}


Table 7 Duncan test results $\left(\mathrm{N} / \mathrm{mm}^{2}\right)$ of the effect of bending strength perpendicular to glue line by glue type Tablica 7. Duncanov test $\left(\mathrm{N} / \mathrm{mm}^{2}\right)$ čvrstoće na savijanje okomito na sljubnicu s obzirom na vrstu ljepila

\begin{tabular}{|l|c|c|}
\hline Glue type / Vrsta ljepila & $\boldsymbol{X}$ & HG \\
\hline Epoxy & 64.42 & A \\
\hline Polyvinyl Acetate (PVAc-D4) & 50.32 & B \\
\hline Polyurethane (PU-D4) & 45.75 & C \\
\hline
\end{tabular}

Table 8 Duncan test results $\left(\mathrm{N} / \mathrm{mm}^{2}\right)$ on the effect of bending strength perpendicular to glue line by glass fiber fabric type

Tablica 8. Duncanov test $\left(\mathrm{N} / \mathrm{mm}^{2}\right)$ čvrstoće na savijanje okomito na sljubnicu s obzirom na vrstu tkanine ojačane staklenim vlaknima

\begin{tabular}{|l|c|c|}
\hline GFRP & $\boldsymbol{X}$ & HG \\
\hline Type 2 / tip 2 & 66.42 & A \\
\hline Type 1 / tip 1 & 50.32 & B \\
\hline Control / kontrola & 43.75 & C \\
\hline
\end{tabular}

According to Table 8 , the highest bending strength was obtained from Type 2 glass fiber fabric samples, followed by Type 1 glass fiber fabric and control samples.

\subsection{Modulus of elasticity parallel to glue line}

3.3. Modul elastičnosti paralelno sa sljubnicom

The statistical evaluation of the results of laminated wood material and modulus of elasticity parallel to glue line is given in Table 9, and the results of multiple variance analysis are given in Table 10.

The effect of the type of glue and glass fiber fabric type was significant with the margin of error ( $p$ $<0.05$ ) in the modulus of elasticity parallel to the glue
Table 11 Duncan test results of the effect of modulus of elasticity $\left(\mathrm{N} / \mathrm{mm}^{2}\right)$ parallel to glue line by glue type Tablica 11. Duncanov test modula elastičnosti $\left(\mathrm{N} / \mathrm{mm}^{2}\right)$ paralelno sa sljubnicom s obzirom na vrstu ljepila

\begin{tabular}{|l|c|c|}
\hline Glue type / Vrsta ljepila & $\boldsymbol{X}$ & HG \\
\hline Epoxy & 5072 & A \\
\hline Polyvinyl Acetate (PVAc-D4) & 3785 & B \\
\hline Polyurethane (PU-D4) & 3775 & B \\
\hline
\end{tabular}

Table 12 Duncan test results of the effect of modulus of elasticity $\left(\mathrm{N} / \mathrm{mm}^{2}\right)$ perpendicular to glue line by glass fiber fabric type

Tablica 12. Duncanov test modula elastičnosti $\left(\mathrm{N} / \mathrm{mm}^{2}\right)$ paralelno sa sljubnicom s obzirom na vrstu tkanine ojačane staklenim vlaknima

\begin{tabular}{|l|c|c|}
\hline GRFP & $\boldsymbol{X}$ & HG \\
\hline Type 2 / tip 2 & 5099 & A \\
\hline Type 1 / tip 1 & 4034 & B \\
\hline Control / kontrola & 3499 & C \\
\hline
\end{tabular}

line. The double interaction of the glue type and glass fiber fabric type $(p<0.05)$ was negligible with respect to the error. Duncan test results applied to determine which groups are different are given in Table 11 by glue type and Table 12 by glass fiber fabric type.

According to Table 11, the highest modulus of elasticity was obtained from epoxy glue and the lowest modulus of elasticity value was obtained from polyurethane (PU-D4) glue.

According to Table 12, it can be seen that the highest modulus of elasticity was obtained from Type 2 glass fiber fabric samples, while the lowest value was obtained from control samples.

Table 9 Modulus of elasticity parallel to glue line $\left(\mathrm{N} / \mathrm{mm}^{2}\right)$

Tablica 9. Modul elastičnosti paralelno sa sljubnicom $\left(\mathrm{N} / \mathrm{mm}^{2}\right)$

\begin{tabular}{|l|l|c|c|c|c|c|}
\hline Glue type / Vrsta ljepila & GFRP & $\boldsymbol{X m i n}$ & $\boldsymbol{X m a x}$ & $\boldsymbol{X}$ & $\boldsymbol{S S}$ & $\mathbf{\%} \boldsymbol{V}$ \\
\hline \multirow{3}{*}{ PVAc-D4 } & Control & 2785 & 3127 & 2956 & 154.34 & 5.200 \\
\cline { 2 - 7 } & Type 1 & 3052 & 3393 & 3223 & 79.22 & 2.400 \\
\cline { 2 - 7 } & Type 2 & 4148 & 4489 & 4318 & 106.22 & 2.400 \\
\hline \multirow{3}{*}{ PU-D4 } & Control & 3878 & 4220 & 4049 & 175.98 & 4.300 \\
\cline { 2 - 7 } & Type 1 & 3270 & 3612 & 3441 & 60.11 & 1.700 \\
\cline { 2 - 7 } & Type 2 & 4440 & 4782 & 4611 & 80.84 & 1.700 \\
\hline \multirow{3}{*}{ Epoxy } & Control & 4150 & 4492 & 4321 & 159.39 & 3.600 \\
\cline { 2 - 7 } & Type 1 & 4520 & 4862 & 4691 & 275.14 & 5.800 \\
\cline { 2 - 7 } & Type 2 & 6115 & 6457 & 6286 & 368.42 & 5.800 \\
\hline
\end{tabular}

$S S$ - standard deviation / standardna devijacija; $V$ - coefficient of variation / koeficijent varijacije

Table 10 Variance analysis results of the effects of glue type and glass fiber fabric type on modulus of elasticity values parallel to glue line

Tablica 10. Rezultati analize varijance utjecaja vrste ljepila i vrste tkanine ojačane staklenim vlaknima na modul elastičnosti paralelno sa sljubnicom

\begin{tabular}{|l|c|c|c|c|c|}
\hline $\begin{array}{l}\text { Source of variance } \\
\text { Izvor varijance }\end{array}$ & $\begin{array}{c}\text { Sum of square } \\
\text { Zbroj kvadrata }\end{array}$ & $\boldsymbol{d f}$ & $\begin{array}{c}\text { Mean square } \\
\text { Prosječni kvadrat }\end{array}$ & $\begin{array}{c}\boldsymbol{F} \text { ratio } \\
\text { F-omjer }\end{array}$ & $\begin{array}{c}\text { Level of significance } \\
\text { Razina značajnosti }\end{array}$ \\
\hline Glue type (A) / vrsta ljepila (A) & 10053593.200 & 2 & 5026796.600 & 1752.657 & 0.000 \\
\hline $\begin{array}{l}\text { Plain woven type (B) } \\
\text { vrsta plošno pletene tkanine (B) }\end{array}$ & 713831.733 & 2 & 3569158.867 & 1244.433 & 0.000 \\
\hline A $\times$ B & 216240.267 & 4 & 54060.067 & 18.849 & 0.053 \\
\hline Residual / ostatak & 103251.600 & 36 & 2868.100 & & \\
\hline Total / ukupno & 348988507.000 & 45 & & & \\
\hline
\end{tabular}


Table 13 Modulus of elasticity perpendicular to glue line $\left(\mathrm{N} / \mathrm{mm}^{2}\right)$

Tablica 13. Modul elastičnosti okomito na sljubnicu $\left(\mathrm{N} / \mathrm{mm}^{2}\right)$

\begin{tabular}{|l|l|c|c|c|c|c|}
\hline Glue type / Vrsta ljepila & GFRP & $\boldsymbol{X m i n}$ & $\boldsymbol{X m a x}$ & $\boldsymbol{X}$ & $\boldsymbol{S S}$ & $\mathbf{\%} \boldsymbol{V}$ \\
\hline \multirow{4}{*}{ PVAc-D4 } & Control & 2772 & 3014 & 2893 & 81.11 & 2.800 \\
\cline { 2 - 7 } & Type 1 & 2613 & 2855 & 2734 & 177.34 & 6.400 \\
\cline { 2 - 7 } & Type 2 & 3726 & 3968 & 3847 & 108.49 & 2.800 \\
\hline \multirow{3}{*}{ PU-D4 } & Control & 3671 & 3912 & 3791 & 73.00 & 1.900 \\
\cline { 2 - 7 } & Type 1 & 3427 & 3669 & 3548 & 191.16 & 5.300 \\
\cline { 2 - 7 } & Type 2 & 4921 & 5163 & 5042 & 96.72 & 1.900 \\
\hline \multirow{3}{*}{ Epoxy } & Control & 4033 & 4275 & 4154 & 53.38 & 1.200 \\
\cline { 2 - 7 } & Type 1 & 4055 & 4296 & 4175 & 225.89 & 5.400 \\
\cline { 2 - 7 } & Type 2 & 5403 & 5645 & 5524 & 70.79 & 1.200 \\
\hline
\end{tabular}

SS - standard deviation / standardna devijacija; $V$ - coefficient of variation / koeficijent varijacije

Table 14 Variance analysis results of the effects of glue type and glass fiber fabric type on modulus of elasticity values perpendicular to glue line

Tablica 14. Rezultati analize varijance utjecaja vrste ljepila i vrste tkanine ojačane staklenim vlaknima na modul elastičnosti okomito na sljubnicu

\begin{tabular}{|l|c|c|c|c|c|}
\hline $\begin{array}{l}\text { Source of variance } \\
\text { Izvor varijance }\end{array}$ & $\begin{array}{c}\text { Sum of square } \\
\text { Zbroj kvadrata }\end{array}$ & $\boldsymbol{d f}$ & $\begin{array}{c}\text { Mean square } \\
\text { Prosječni kvadrat }\end{array}$ & $\begin{array}{c}\boldsymbol{F} \text { ratio } \\
\text { F-omjer }\end{array}$ & $\begin{array}{c}\text { Level of significance } \\
\text { Razina značajnosti }\end{array}$ \\
\hline Glue type (A) / vrsta ljepila (A) & 9120065.644 & 2 & 4560032.822 & 1754.189 & 0.000 \\
\hline $\begin{array}{l}\text { Plain woven type (B) } \\
\text { vrsta plošno pletene tkanine (B) }\end{array}$ & 6474541.111 & 2 & 3237270.556 & 1245.338 & 0.000 \\
\hline A $\times$ B & 196258.622 & 4 & 49064.656 & 18.875 & 0.052 \\
\hline Residual / ostatak & 93582.400 & 36 & 2599.511 & & \\
\hline Total / ukupno & 316532875.000 & 45 & & & \\
\hline
\end{tabular}

\subsection{Modulus of elasticity perpendicular to glue line}

3.4. Modul elastičnosti okomito na sljubnicu

The statistical evaluation results of modulus of elasticity of laminated wood material and solid wood are given in Table 13, and the results of multiple variance analysis are given in Table 14.

The effect of the type of glue and glass fiber fabric type was significant with the margin of error $(p<0.05)$ in the modulus of elasticity perpendicular to the glue line. The double interaction of the glue type and glass fiber fabric type $(p<0.05)$ was negligible with respect to the error. Duncan test results applied to determine which groups are different are given in Table 11 by glue type and Table 12 by glass fiber fabric type. Duncan test results applied to determine which groups are different are given in Table 15 by glue type and Table 16 by glass fiber fabric type.

The highest modulus of elasticity value was obtained with epoxy glue, followed by polyvinyl acetate grafted (PVAc-D4) and polyurethane grafted (PU-D4), respectively.

According to Table 16, it can be seen that the highest modulus of elasticity was obtained from Type 2 , while the lowest value was obtained from control samples.

As a result, it was determined that epoxy glue has higher strength than polyurethane and polyvinyl acetate glues; Type 2 plain weaving woven fabric has higher strength than Type 1 plain weaving woven fabric; and laminates parallel to the glue line have higher performance than those perpendicular to the glue line. In recent years, some research has been carried out on the
Table 15 Duncan test results of the effect of modulus of elasticity $\left(\mathrm{N} / \mathrm{mm}^{2}\right)$ perpendicular to glue line by glue type Tablica 15. Duncanov test modula elastičnosti $\left(\mathrm{N} / \mathrm{mm}^{2}\right)$ okomito na sljubnicu s obzirom na vrstu ljepila

\begin{tabular}{|l|c|c|}
\hline Glue type / Vrsta ljepila & $\boldsymbol{X}$ & HG \\
\hline Epoxy & 4805 & A \\
\hline Polyvinyl Acetate (PVAc-D4) & 3613 & B \\
\hline Polyurethane (PU-D4) & 3486 & C \\
\hline
\end{tabular}

Table 16 Duncan test results of the effect of modulus of elasticity $\left(\mathrm{N} / \mathrm{mm}^{2}\right)$ perpendicular to glue line by glass fiber fabric type

Tablica 16. Duncanov test modula elastičnosti $\left(\mathrm{N} / \mathrm{mm}^{2}\right)$ okomito na sljubnicu s obzirom na vrstu tkanine ojačane staklenim vlaknima

\begin{tabular}{|l|c|c|}
\hline GFRP & $\boldsymbol{X}$ & HG \\
\hline Type 2 / tip 2 & 4618 & A \\
\hline Type 1 / tip 1 & 4127 & B \\
\hline Control / kontrola & 3158 & C \\
\hline
\end{tabular}

mechanical reinforcement of glass fiber and wood-based structural materials (Basterra et al., 2012; Mistak, 2013; Bal and Ozyurt, 2015; Guntekin 2015). In these studies, the researchers generally made experiments on the bending properties and adhesion strength of the reinforced material. Premrov et al., (2003) investigated the mechanical strengths of wooden structural elements reinforced with carbon fiber, and they obtained a $50 \%$ higher strength in the bending strength of laminated elements. Gaff and Gaffrik (2015) also examined the effect of bending strength of laminated beech wood on densification. As a result, the bending strength value was found to 
be $17 \%$ higher than the control sample. Muratoglu (2011) achieved high strength with carbon fiber reinforced strip rod (CFRP) and double component epoxy adhesive in reinforcement processes in the restoration of historical buildings.

\section{CONCLUSIONS}

\section{ZAKLJUČAK}

In this study, the modulus of elasticity of the laminated wood material supported by various glass fiber materials was investigated from 4 aspects. To this purpose (Populus nigra.) wood, which is widely used in the manufacture of furniture and building elements in our country, was made of 4 layers of glass fiber elements placed in porous structure between slats and bonded with epoxy, polyvinyl acetate (PVAc-D4) and polyurethane (PU-D4). As a result of the test, control samples and samples supported by glass fiber fabric were statistically evaluated according to the glue type, glass fiber type and load type. Based on the results, epoxy adhesive showed the highest bending strength parallel and perpendicular to the glue line, while polyurethane (PU-D4) glue showed the lowest bending strength. According to the glass reinforcing fiber type, Type 2 showed the highest bending strength, while the control samples showed the lowest bending strength. Epoxy + Type 2 showed the highest bending strength combined with glue type and glass reinforcing fiber type. Epoxy adhesive showed the highest modulus of elasticity strength parallel and perpendicular to the glue line, while polyurethane (PU-D4) glue showed the lowest bending strength. Regarding the type of glue, epoxy adhesive showed the highest modulus of elasticity perpendicular to the glue line, while polyurethane (PU-D4) glue showed the lowest modulus of elasticity value. Epoxy + Type 2 showed the highest modulus of elasticity combined with glue type and glass reinforcing fiber type.

Based on the experimental results obtained, it was determined that the bending strength and the modulus of elasticity increased the strength of the support materials as compared to the control example. Since there is a significant increase in the strength properties of the material when using the intermediate filler material in the laminated materials, its use may be preferred in furniture and building properties. In the literature, it is stated that the performance will increase as a result of the increase of layer thickness in pine samples. As a continuation of this study, researchers are recommended to focus on different layer symmetry and testing of laminated samples with different filling materials.

\section{REFERENCES}

\section{LITERATURA}

1. Akgul, T.; Apay, A.; Sarıbıyık, M., 2009: Reinforcement of wooden joints by glass fiber reinforced plastics. $5^{\text {th }}$ International Symposium on Advanced Technologies (IATS'09) 13-15 May 2009, Istanbul, Turkey. Paper ID: 621.
2. Altınok, M.; Ozalp, M.; Kızılırmak, H.; Yesil, H., 2009: Determination of lamination properties of chestnut wood. Istanbul University Forestry Faculty Journal, 59 (1): 1525.

3. Baird, J. A.; Ozelton, E. C., 1990: Timber designer manual. Great Britain.

4. Bal, B. C., 2014a: Flexural properties, bonding performance and splitting strength of lvl reinforced with woven glass fiber. Construction and Building Materials, 51: 9-14. http://dx.10.1016/j.conbuildmat.2013.10.041.

5. Bal, B. C., 2014b: Some physical and mechanical properties of laminated veneer lumber reinforced with woven glass fiber. Construction and Building Materials, 68: 120126. http://dx.10.1016/j.conbuildmat.2014.06.042.

6. Bal, B. C.; Ozyurt, H., 2015: Some technological properties of laminated wood flooring. KSU Journal of Engineering Sciences, 18 (1): 9-16.

7. Basterra, L. A; Acuna, L.; Casado, M.; Lopez, G.; Bueno, A., 2012: Strength testing of poplar duo beams, populus $\mathrm{x}$ euramericana (done) guiniercv. i-214 with fibre reinforcement. Construction and Building Materials, 36: 9096. http://dx.10.1016/j.conbuildmat.2012.05.001.

8. Biblis, E. J., 1965: Analysis of wood-fiberglass composite beams within and beyond the elastic region. Forest Products Journal, 15 (2): 81-89.

9. Bobat, A., 1994: Use of impregnated wood material in closed mines and in the sea. KTU, Graduate School of Natural and Applied, Trabzon.

10. Braun, M. O.; Moody, R. C., 1977: Bending strength of small beams with a laminated veneer tension lamination. Forest Product Journal, 27 (1): 46-50.

11. Brunner, M.; Schnueriger, M., 2005: Timber beams strengthened by attaching prestressed carbon frp laminates with a gradient anchoring device. Proceedings of the Intr. Symp. on Bond Behavior of FRP in Structures.

12. Dilik, T., 1997: Window profile production from laminated wood material and determination of some quality characteristics. Istanbul University Institute of Science and Technology, Unpublished $\mathrm{PhD}$ Thesis.

13. Dongel, N., 1999: Effects of wood type, number of layers and glue types on flexural strength of laminated wood materials. Gazi University Institute of Science and Technology, Unpublished Master Thesis.

14. Eckelman, C. A., 1993: Potential uses of laminated veneer lumber in furniture, department of forestry and natural resources. Forest Product Journal, 43 (4): 19-24.

15. Fiorelli, J.; Dias, A., 2006: Fiberglass-reinforced glulam beams: mechanical properties and theoretical model. Materials Research, 9 (3): 263-269. http://dx.10.1590/S1516-14392006000300004.

16. Gaff, M.; Gasparik, M., 2015: Densified beech veneer. BioResources, 10 (1): 1506-1518.

17. Guntekin, E.; Aydın, T. Y., 2015: Effect of strengthening of glass reinforcement and steel plate on flexural performance of plate lumber produced from red pine (Pinusbrutia Ten.). Kastamonu University Journal of Faculty of Forestry, 15 (1): 73-77.

18. Guray, A.; Kılıc, M.; Dogru, G.; Ozer, M., 2003: The effect of power direction and type of glue on the flexural strength of laminated wood produced from oak (Quercus Robur L.) wood. Journal of Technology, 6 (1-2): 1-9.

19. Hallstrom, S.; Grenestedt, J. L., 1997: Failure analysis of laminated timber beams reinforced with glass fiber composites. Wood Science and Technology, 31: 17-34.

20. Keskin, H., 2001: Technological properties of laminated solid wood materials and their use in woodworking industry. Gazi University, Institute of Science and Technology, Unpublished PhD Thesis. 
21. Keskin, H.; Togay, A., 2003: Some physical and mechanical properties of laminated wood materials produced by eastern beech and black poplar combination. SDU, Journal of Forestry Faculty, 2: 101-114.

22. Kurtoglu, A., 1979: Formation of stresses due to moisture change in bonded wood material. Istanbul University, Journal of Forestry Faculty, 29 (2).

23. Mistak, O., 2013: Determination of the mechanical properties of laminated wood materials obtained with scotch wood materials and different fiber (FRP) fabrics. Master Thesis, Karabuk University, Journal of Science, pp. 4966.

24. Moody, R. C., 1981: Compressive strength of one-and two-ply laminated timbers. Forest Product Journal, 31 (5): 47-50.

25. Muratoglu, A., 2011: Reinforcement of wooden building elements with carbon fiber reinforced polymers (CFRP) in restoration. Master Thesis, Karabuk University Institute of Science Karabuk, pp. 42-77.

26. Osmannezhad, S.; Faezipour, M.; Ebrahimi, G., 2014: Effects of GFRP on bending strength of glulam made of poplar (Populus deltoids) and beech (Fagus orientalis), Construction and Building Materials, 51: 34-39. http://dx.10.1016/j.conbuildmat.2013.10.035.

27. Ozalp, M.; Atılgan, A.; Esen, Z.; Kaya, S., 2009: Comparing the resistance and bending in the plywoods which each made with different glues. DPU, Journal of Graduate School of Natural and Applied Sciences, 18: 99-104.

28. Percin, O.; Ozbay, G.; Ordu, M., 2009: The Investigation of the mechanical properties of wooden materials laminated with various glues. DPU Institute of Science and Technology, 19: 109-120.

29. Pidaparti, R. M. V.; Johnson, K., 1996: Composite lamination onto wood. Polymers and Polymer Composites, 4 (2): $125-128$.

30. Premrov, M., Dobrila, P., Bedenik, B. S., 2003: Analysis of timberframed walls coated with CFRP strips strengthened fibre-plaster boards. Faculty of Civil Engineering, Universty of Maribor, Slovenia, pp. 1-12.

31. Ribeiro, A. S.; Jesus, A. M. P.; Lima, A. M.; Lousada, J. L. C., 2009: Study of strengthening solutions for gluedlaminated wood beams of maritime pine wood. Construction and Building Materials, 23 (8): 2738-2745. http://dx.10.1016/j.conbuildmat.2009.02.042.

32. Salih, E., 1998: The effect of glue type and logging time on some physical and mechanical properties of laminated substrates produced from eucalyptus (E. Camaldulensis) wood. KTU, Graduate School of Natural and Applied Science, Unpublished Master Thesis.
33. Senay, A., 1996: Determination of mechanical properties of wooden laminated carrier elements. IU, Graduate School of Natural and Applied Science, Unpublished PhD Thesis.

34. Theakston, F. H., 1965: A feasibility study for strengthening timber beams with fiberglass. Canadian Agricultural Engineering, January: 17-19.

35. Ulupınar, M., 1998: Determination of technological properties of laminated poplar (Populus Euramericana). Master Thesis. Hacettepe University, Institute of Science and Technology, Ankara, pp. 92.

36. Wangaard, F. F., 1964: Elastic deflection of wood-fiberglass composite beams. Forest Product Journal, 13 (6): 256-260.

37. Youngquist, J. A.; Laufenberg, T. L.; Bryant, B. S., 1984: End Jointing of laminated veneer lumber for structural usage. Forest Product Journal, 34: 11-12.

38. ***DIN 68140, 1998: Finger joints in wood, Part 1: Finger jointed structural timber. Deutsche Norm, Berlin

39. ***Dost Kimya, 2017: Chemistry Company, 2017.

40. ***Franklin Glue Comp., 1989: Adhesive trouble shooting. Colombus, USA.

41. ***Polisan, 2017. Chemistry Company, KOCAELİ.

42. ***TS EN 386, 1999: Glued laminated wood performance properties and minimum production conditions. TSE, Ankara.

Note: This paper was oraly presented at the $3^{\text {rd }}$ International Congress on Engineering, Architecture and Design on May 4-5 2018 in Kocaeli, Turkey. The summary of the paper entitled as "Some Mechanical Properties of Poplar Laminated Wood Material Reinforced with Fabric Glass Fiber" was published in the Book of abstracts.

\section{Corresponding address:}

\section{ABDURRAHMAN KARAMAN, PhD}

University of Usak

Forestry and Forestry Production Programme

Banaz Vocational School

64500, Banaz/Usak, TURKEY

e-mail: abdurrahman.karaman@usak.edu.tr 